\title{
Sosialisasi Kelas LIBUR (Kelas Ibu Balita Gibur) tentang Pemberian Makanan Tambahan pada Bayi Balita Gizi Buruk dan Kurang di Puskesmas Jenggot Kota Pekalongan
}

\author{
Pedvin Ratna Meikawati ${ }^{1}$, Maslikhah ${ }^{2}$ \\ email : pedvin_ratna@yahoo.com \\ DIII Kebidanan Harapan Ibu Pekalongan \\ Jl. Sriwiaya No. 7 Pekalongan \\ Hp 085641541222
}

\begin{abstract}
Abstrak
Usia balita (bawah lima tahun) merupakan masa yang penting dalam proses tumbuh kembang manusia, dimana pada periode ini pertumbuhan dan perkembangan berlangsung dengan sangat cepat. Proses pertumbuhan dan perkembangan anak yang berlangsung dengan cepat membawa konsekuensi meningkatnya kebutuhan nutrisi yang adekuat. Gizi kurang merupakan salah satu faktor yang secara signifikan berhubungan dengan peningkatan risiko penyakit infeksi pernafasan akut, diare, campak dan beberapa penyakit infeksi lainnya. Kondisi yang demikian akan semakin memperburuk status gizi anak. Apabila hal tersebut terus berlangsung maka risiko kematian pada anak akan meningkat.

Berdasarkan Laporan Program Gizi di Puskesmas Jenggot Kota Pekalongan, tahun 2018 terdapat 13 balita dengan status gizi buruk $9(\mathrm{BB} / \mathrm{U})$ dengan 1 balita dengan status gizi sangat kurus (BB/TB). Hal ini menunjukkan bahwa masih banyak balita yang mengalami gizi buruk (BB/U) dan perlu penanganan khusus dalam mengatasi hal tersebut. Kegiatan pengabdian masyarakat ini bertujuan untuk meningkatkan pengetahuan, sikap dan praktik ibu balita tentang gizi buruk dan menyusun makanan atau cemilan yang sehat. Dilakukan pretest dan posttest untuk mengetahui pengetahuan ibu yang memiliki bayi dan balita dengan status gizi buruk dan kurang. Hasil yang diperoleh yaitu adanya peningkatan pengetahuan baik ibu balita yang setelah diberikan perlakuan, yang semula 33,3\% menjadi $60 \%$. Puskesmas rutin untuk melakukan kelas ibu balita dengan variatif dalam penyampaiannya, Akademisi atau instasi-instasi lain yang bersangkutan, untuk selalu memberikan penyuluhan-penyululuhan bagi ibu balita
\end{abstract}

Kata kunci : Bayi Balita, Kelas LIBUR, Makanan tambahan, Gizi,

\begin{abstract}
Toddler age (under five years) is an important period in the process of human growth and development, where in this period growth and development takes place very quickly. The process of growth and development of children that takes place quickly brings the consequences of increasing nutritional needs that are adequate. Poor nutrition is one of the factors that is significantly associated with an increased risk of acute respiratory infections, diarrhea, measles and several other infectious diseases. Such conditions will further worsen the nutritional status of children. If this continues, the risk of death in children will increase.

Based on the Nutrition Program Report at the Pekalongan City Jenggot Health Center, in 2018 there were 13 infants with poor nutritional status 9 (BB / U) with 1 toddler with very thin nutritional status (BB / TB). This shows that there are still many children under five suffering from malnutrition (BB / U) and need special handling in overcoming this. This community service activity aims to increase the knowledge, attitudes and practices of toddlers about malnutrition and to compile healthy foods or snacks. Pretest and posttest were conducted to find out the knowledge of mothers who have babies and toddlers with poor and malnourished status. The results obtained are an increase in knowledge both mothers of children under five who after being given treatment, which was originally $33.3 \%$ to $60 \%$. Routine Puskesmas to conduct classes for toddlers with varied in delivery, Academics or other related institutions, to always provide counseling for mothers of toddlers
\end{abstract}

Keywords: Toddler Babies, LIBUR Class, Additional Foods, Nutrition. 


\section{Pendahuluan}

Usia balita (bawah lima tahun) merupakan masa yang penting dalam proses tumbuh kembang manusia, dimana pada periode ini pertumbuhan dan perkembangan berlangsung dengan sangat cepat. Proses pertumbuhan dan perkembangan anak yang berlangsung dengan cepat membawa konsekuensi meningkatnya kebutuhan nutrisi yang adekuat (1). Asupan nutrisi yang tidak adekuat dapat berdampak pada menurunnya daya tahan tubuh anak sehingga anak menjadi mudah terserang penyakit infeksi. Gizi kurang merupakan salah satu faktor yang secara signifikan berhubungan dengan peningkatan risiko penyakit infeksi pernafasan akut, diare, campak dan beberapa penyakit infeksi lainnya. Kondisi yang demikian akan semakin memperburuk status gizi anak. Apabila hal tersebut terus berlangsung maka risiko kematian pada anak akan meningkat. Menurut World Health Organization (WHO) pada tahun 2002 sebanyak 54\% kematian balita disebabkan oleh gizi buruk ${ }^{(2)}$.

Berdasarkan hasil Riset

Kesehatan Dasar (Riskesdas) Kementerian Kesehatan 2018 menunjukkan $17,7 \%$ bayi usia di bawah 5 tahun (balita) masih mengalami masalah gizi. Angka tersebut terdiri atas balita yang mengalami gizi buruk sebesar 3,9\% dan yang menderita gizi kurang sebesar 13,8\%. Saat ini angka stunting di Jawa Tengah (Jateng) masih cukup tinggi yakni sekitar $30 \%$ dari jumlah anak balita sebanyak 2,5 juta. Berdasarkan data Dinas Kesehatan (Dinkes) Jateng angka anak balita gizi buruk pada tri wulan 2019 tercatat sebanyak 1.276 kasus $^{(3)}$.

Berdasarkan Laporan Program Gizi di Puskesmas Jenggot Kota
Pekalongan, tahun 2018 terdapat 13 balita dengan status gizi buruk 9 $(\mathrm{BB} / \mathrm{U})$ dengan 1 balita dengan status gizi sangat kurus (BB/TB). Hal ini menunjukkan bahwa masih banyak balita yang mengalami gizi buruk $(\mathrm{BB} / \mathrm{U})$ dan perlu penanganan khusus dalam mengatasi hal tersebut. Di masyarakat, balita dengan status gizi buruk dengan indikator $\mathrm{BB} / \mathrm{U}$ lebih dikenal dengan balita BGM.

Faktor-faktor yang

berhubungan dengan balita gizi buruk adalah pengetahuan ibu balita, status ekonomi keluarga balita, kecukupan energi dan protein balita dan penyakit penyerta balita ${ }^{(4)}$. Pengetahuan ibu sangat berpengaruh dalam hal terjadinya gizi buruk. Pengetahuan ibu dalam pengaturan konsumsi makanan dengan pola makan seimbang sangat diperlukan untuk menjadikan balita memiliki status gizi baik. Pengetahuan gizi ibu meliputi mampu membuat makanan yang memiliki komposisi beraneka ragam atau bervariasi untuk dikonsumsi balita sehingga kebutuhan zat gizi balita dapat tercukupi. Selain pengetahuan ibu, pola asuh sama halnya dengan pola asuh gizi. Dalam hal pemberian makan dan pemeliharaan kesehatan dapat dilihat pola perilaku ibu dalam mengasuh anaknya ${ }^{(5)}$ Tercukupinya kebutuhan gizi akan menyebabkan balita terhindar dari gizi kurang. Oleh sebab itu, peran pengetahuan ibu sangat penting dalam peningkatan status gizi pada balita $^{(6)}$. Apabila ibu memiliki pengetahuan gizi yang baik maka ibu akan memperhatikan keadaan gizi setiap akan memberikan makan pada balita.

Masalah kurang gizi memperlambat pertumbuhan ekonomi dan mendorong proses pemiskinan melalui tiga cara, pertama, kurang gizi secara langsung menyebabkan hilangnya produtivitas karena kelemahan 
fisik. Kedua, kurang gizi secara tidak langsung menurunkan kemampuan fungsi kognitif dan berakibat pada rendahnya tingkat pendidikan. Ketiga, kurang gizi dapat menurunkan tingkat ekonomi keluarga karena meningkatnya pengeluaran untuk berobat. Sebagaimana yang disebutkan dalam Peraturan Menteri Kesehatan Republik Indonesia Nomor 23 Tahun 2014 tentang Upaya Perbaikan Gizi, pasal 2, bahwa Pengaturan upaya perbaikan gizi ditujukan untuk menjamin : (a). Setiap orang memiliki akses terhadap informasi gizi dan pendidikan gizi, (b). Setiap orang terutama kelompok rawan gizi memiliki akses terhadap pangan yang bergizi, dan (c). Setiap orang memiliki akses terhadap pelayanan gizi dan kesehatan. Dalam Peraturan Menteri Kesehatan Republik Indonesia Nomor 23 Tahun 2014 tentang Upaya Perbaikan Gizi, Pasal 5 menjelaskan bahwa Pemerintah bertugas dan bertanggung jawab : (a). Menyusun dan menetapkan kebijakan bidang gizi; (b). Melakukan koordinasi, fasilitasi dan evaluasi surveilans kewaspadaan gizi skala nasional; (c). Melakukan penanggulangan gizi buruk skala nasional; (d). Mengatur, membina, dan mengawasi pelaksanaan urusan wajib upaya perbaikan gizi; (e). Mengupayakan pemenuhan kecukupan dan perbaikan gizi pada masyarakat terutama pada keluarga miskin, rawan gizi, dan dalam situasi darurat; (f). Meningkatkan pengetahuan dan kesadaran masyarakat akan pentingnya gizi dan pengaruhnya terhadap peningkatan status gizi.

Berdasarkan latar belakang diatas, maka perlu diadakannya kelas ibu balita BGM dimana ibuibu yang mempunyai balita BGM dapat berdiskusi, tukar pendapat, tukar pengalaman akan gizi balita BGM yang dibimbing oleh petugas gizi dan petugas kesehatan lainnya. Dengan Kelas Ibu Balita BGM yang dibimbing oleh petugas gizi dan petugas kesehatn lainnya dapat mebrikan penyuluhan gizi dan kesehatn balita BGM sehingga dapat meningkatkan pengetahuan ibu tentang gizi balita. Agar kegiatan ini lebih menarik, maka munculah nama kegiatan "Kelas Libur (Kelas Ibu Balita Gizi Buruk)' agar masyarakat lebih tertarik dan memberikan perhatian khusus terhadap kegiatan ini.

Kegiatan pengabdian masyarakat ini bertujuan untuk meningkatkan pengetahuan, sikap dan praktik ibu balita tentang gizi buruk dan menyusun makanan atau cemilan yang sehat.

\section{Metode}

Pelaksanaan kegiatan ini menggunakan penyuluhan tentang gizi buruk dan makanan tambahan yang sehat bagi balita, diawali dengan pre test, dan untuk mengevalusi hasil penyuluhan dilakukan post test design. Kegiatan ini dilaksanaakan di Puskesmas Jenggot Kota Pekalongan pada tanggal 29 Maret 2019. Sasaran ibu yang memiliki bayi dan balita dengan status gizi buruk dan kurang sejumlah $15 \mathrm{ibu}$ balita. Kriteria yang diutamakan adalah ibu dengan status ekonomi yang sulit dan bersedia mengikuti kegiatan ini sampai selesai. Tahapan dalam kegiatan ini berupa : (1) pre test tentang gizi buruk dan pemberian makanan tambahan yang sehat, (2) Pemberian penyuluhan tentang gizi buruk dan pemberian makanan tambahan yang sehat, (3) post test tentang gizi buruk dan pemberian makanan tambahan yang sehat. Data dalam kegiatan ini berupa data primer yaitu data berasal dari responden langsung. Instrumen kegiatan ini berupa 
kuesioner tertutup sejumlah 10 soal dengan jawaban benar dan salah. Selanjutnya data yang telah terkumpul dilakukan analisis data dengan menggunakan uji univariate.

\section{Hasil dan Pembahasan}

Puskesmas jenggot hanya memiliki satu wilayah kerja yaitu kelurahan Jenggot, dengan luas wilayah $123.500 \mathrm{KM}^{2}$, jumlah RW 11, RT 44 dan jumlah penduduk 12.132 jiwa dengan usia $0-1$ bulan berjumlah 43 jiwa dan jumlah balita sebanyak 49 jiwa. Kegiatan pengabdian masyarakat sosilisasi kelas Libur (Kelas Ibu Balita Gizi Buruk dan kurang) dan pemberian makanan tambahan yang sehat di Puskesmas Jenggot diawali dengan survey tempat pengabdian kepada masyarakat dan persiapan kuesioner yang akan digunakan untuk pre test dan post test kegiatan ini. Kegiatan ini bertujuan untuk memberikan edukasi kepada ibu balita tentang gizi buruk dan kurang serta pemberian makanan tambahan yang sehat sehingga dapat meningkatkan pengetahuan ibu tentang makanan tambahan yang sehat untuk balita dan apada akhirnya ibu juga dapat menyusun makanan tambahan yang sehat untuk balita nya di rumah.

Kegiatan pengadian kepada masyarakat ini telah dilaksanakan pada hari Jum'at, 29 Maret 2019 bertempat di Aula Puskesmas Jenggot Kota Pekalongan.

Tabel 1. Distribusi Tingkat Pengetahuan Ibu Balita sebelum dan Setelah diberikan Penyuluhan tentang gizi buruk dan pemberian makanan tambahan yang sehat di Puskesmas Jenggot 29 Maret 2019. ( $\mathrm{n}=15)$

\begin{tabular}{ccc}
\hline Pengetahuan & $\begin{array}{c}\text { Sebelum } \\
\text { Perlakuan }\end{array}$ & $\begin{array}{c}\text { Setelah } \\
\text { perlakuan }\end{array}$ \\
\hline Baik & $5(33,3 \%)$ & $9(60 \%)$ \\
\hline Cukup & $4(26,7 \%)$ & $5(33,3 \%)$ \\
\hline Kurang & $6(40 \%)$ & $1(6,7 \%)$ \\
\hline
\end{tabular}

Pada tabel 1 dapat dilihat bahwa ibu balita setelah diberikan perlakuan berupa penyuluhan gizi buruk dan pemberian makanan tambahan yang sehat, tingkat pengetahuannya semakin meningkat terlihat bahwa ibu dengan tingkat pengetahuan baik yang awalnya $33,3 \%$ menjadi $60 \%$, dan tingkat pengetahuan kurang yang awalnya sebelum perlakukan $40 \%$ mengalami penurunan menjadi $6,7 \%$.

Hasil dari kegiatan ini dapat berjalan dan dapat diterima dengan baik, dengan ditandai, ketertarikan ibu balita yang mengajukan beberapa pertanyaan dan hasil evaluasi pre test dan post test .

\section{Kesimpulan}

Kegiatan pengadian masyarakat ini "Sosialisasi Kelas LIBUR (Kelas Ibu Balita Gibur) Tentang Pemberian Makanan Tambahan Pada Bayi Balita Gizi Buruk dan Kurang Di Puskesmas Jenggot Kota Pekalongan berjalan dengan lancar dan antusias ibu balita yang tertarik dengan materi tersebut. Adanya peningkatan pengetahuan baik ibu balita yang setelah diberikan perlakuan, yang semula $33,3 \%$ menjadi $60 \%$. Puskesmas rutin untuk melakukan kelas ibu balita dengan variatif dalam penyampaiannya, Akademisi atau instasi-instasi lain yang bersangkutan, untuk selalu memberikan penyuluhanpenyuluhan bagi ibu balita. 
5. Daftar Pustaka

[1] Hartono 2008. Tumbuh

Kembang Anak dan

Remaja, Jakarta: Sagung

Seto.

[2] Putri RF, Sulastri D, Lestari Y, 2015.

[3] https://www.gatra.com/deta il/news/461934/kesehatan/i ni-langkah-dinkes-jatengturunkan-angka-stunting.

[4] Silvera Oktavia. 2017. Faktor-faktor yang berhubungan dengan status gizi buruk pada balita di Kota Semarang tahun 2017 (Studi di Rumah Pemulihan Gizi Banyumanik Kota Semarang. Jurnal Kesehatan .
[5] Veriyal. N. 2010. Analisis Pola Asuh terhadap Balita Kurang Energi Protein (KEP) yang mendapatkan PMT-P di Puskesmas Pagedangan Kabupaten Tangerang Jakarta. Universotas Islam Negeri Hidayatulloh. Skripsi.

[6] Almatsier, Sunita. 2002. Prinsip Dasar Ilmu Gizi. Jakarta .Gramedia Pustaka Utama. 